\title{
ANALISIS POTENSI RASIO CAMEL SEBAGAI INDIKATOR SINYAL KONDISI BERMASALAH \\ BANK PERKREDITAN RAKYAT KONVENSIONAL DAERAH ISTIMEWA YOGYAKARTA
}

\author{
Gendro Wiyono \\ Program Studi Magister Manajemen \\ Fakultas Ekonomi Universitas Sarjanawiyata Tamansiswa \\ E-mail: Gw1@doctor.com
}

\begin{abstract}
The study was conducted to determine the potential of camel ratio as an indicator of signal problematic conditions of Conventional Rural Bank in Yogyakarta Special Region. The data used are all the Performance Rural Banks operating in 4 (four) districts and 1 (one) city of Yogyakarta, which is listed on the Bank of Indonesia. Due dependent variable is nominal data, then test of hypothesis is done using logit regression analysis model. The results provide evidence that: Adequacy Capital Ratio $\left(Z_{\text {statistics }}=-5.4477\right.$; sig. $\left.=0.0000\right)$ as a proxy for capital potentially significant factor as an indicator of signal problematic conditions; Non Performance Loan $\left(Z_{\text {Statistics }}=6.3545 ;\right.$ sig. $\left.=0.0000\right)$ and Depreciation Reserve of Productive Assets $\left(Z_{\text {statistics }}=3.6966 ;\right.$ sig. $\left.=0.0002\right)$ as a proxy for asset quality factor potentially significant as an indicator of signal problematic conditions; Profit Margin ( $z$ statistics $=$ 1.3183; Sig. $=0.1874)$ as a proxy for management factor and Return On Assets ( $z$ statistics $=0.1402$; sig. $=0,8884)$ as a proxy for earnings factor is not significant as an indicator of potentially problematic conditions signal; and Loan to Deposit Ratio $(z$ Statistics $=-$ 4.3700 ; sig. $=0.0000)$ as a proxy for liquidity potentially significant factor as an indicator of signal problematic conditions.
\end{abstract}

\section{A. LATAR BELAKANG}

Perkembangan Bank Perkreditan Rakyat (BPR) begitu pesatnya, sehingga BPR berperan mendorong pertumbuhan ekonomi daerah terutama ditingkat bawah dan telah mengakar pada sistem sosial ekonomi masyarakat pedesaan maupun perkotaan. Berdasarkan Undang-Undang Republik Indonesia No. 7 tahun 1992 tentang Perbankan, sebagaimana telah diubah dengan Undang-Undang No. 10 Tahun 1998, BPR adalah Bank yang melaksanakan kegiatan usaha secara konvensional atau berdasarkan Prinsip Syariah yang dalam kegiatannya memberikan jasa dalam lalu lintas pembayaran. Eksistensi BPR dimaksudkan secara khusus untuk menjangkau masyarakat dari golongan ekonomi lemah dan pengusaha kecil baik di pedesaan maupun di perkotaan. Dalam hal lainnya, BPR cenderung menerapkan mekanisme pelayanan jasa yang lebih sederhana, namun tingkat suku bunga yang lebih tinggi, dan lebih bersikap proaktif dalam mencari nasabah dibandingkan dengan bank umum.

Dengan perbedaan karakteristik tersebut BPR perlu ditinjau secara khusus, dimana tinjauan terhadap bank umum belum tentu sesuai dengan kondisi BPR. Namun demikian seiring dengan perkembangannya, persaingan dan kompleksitas usaha BPR juga menghadapi risiko yang meningkat, sehingga tidak sedikit BPR yang bermasalah. Permasalahan perbankan di Indonesia antara lain disebabkan depresiasi rupiah, peningkatan suku bunga Sertifikat Bank 
Indonesia (SBI) sehingga menyebabkan meningkatnya kredit bermasalah. Berbagai seminar telah dilaksanakan menyimpulkan, antara lain: (1). Semakin meningkatnya kredit bermasalah perbankan; (2) Dampak likuidasi bank 1 Nopember 1997 yang mengakibatkan turunnya kepercayaan masyarakat terhadap perbankan dan pemerintah, sehingga memicu penarikan dana secara besar-besaran; (3) semakin menurunnya pemodalan;

Ketidakmampuan melunasi kewajibannya karena menurunnya nilai rupiah; Pelanggaran BMPK (Batas Maksimum Pemberian Kredit); (6) Modal Bank atau Capital Adequacy Ratio (CAR) belum mencerminkan kemampuan riil untuk menyerap berbagai resiko kerugian dan (7) Manajemen yang tidak profesional.

Salah satu pendekatan yang dapat digunakan untuk mengetahui kinerja bank adalah rasio keuangan yang dikenal dengan CAMEL yang meliputi: Capital, Assets quality, Management, Earnings, dan Liquidity. Dalam prakteknya CAMEL digunakan sebagai indikator penilaian kesehatan bank umum sebagimana tertuang dalam Peraturan Bank Indonesia (PBI) No.6/10/PBI/2004 tanggal 12 April 2004 dan Surat Edaran No.6/23/DPNP tanggal 31 Mei 2004 tentang Sistem Penilaian Tingkat Kesehatan Bank Umum. Khusus untuk BPR, ditetapkan dengan Surat Keputusan Direksi Bank Indonesia. No. 30/12/KEP/DIR tanggal 30 April 1997 dan Surat Edaran No.30/3/UPPB tanggal 30 April 1997 tentang Tata Cara Penilaian Tingkat Kesehatan Bank Perkreditan Rakyat. Hasil pengukuran berdasarkan alat analisis CAMEL diterapkan untuk menentukan tingkat kesehatan bank yang dikategorikan dalam empat predikat yaitu: "Sehat", "Cukup Sehat", "Kurang Sehat" dan "Tidak

Tingkat kesehatan bank dapat dinilai menggunakan beberapa indikator. Salah satu indikator utama yang sering dijadikan dasar penilaian adalah laporan keuangan bank yang bersangkutan. Berdasarkan laporan keuangan dapat dihitung sejumlah rasio keuangan yang lazim dijadikan dasar penilaian tingkat kesehatan bank. Analisis rasio keuangan memungkinkan pihak manajemen untuk mengidentifikasikan perubahanperubahan pokok pada trend jumlah, dan hubungan serta alasan perubahan tersebut. Hasil analisis laporan keuangan dapat membantu menginterpretasikan berbagai hubungan kunci serta kecenderungan yang dapat memberikan dasar pertimbangan mengenai potensi keberhasilan perusahaan di masa mendatang. Informasi tentang posisi keuangan perusahaan, kinerja perusahaan, aliran kas perusahaan dan informasi lain yang berkaitan dengan laporan keuangan dapat diperoleh berdasarkan laporan keuangan bank.

Penelitian ini berusaha untuk mengetahui persoalan yang berkaitan dengan penilaian kinerja bank dilihat dari sinyal kondisi bermasalah bank dengan menganalisis secara empiris data tentang kinerja bank melalui rasio keuangannya. Konsep dasar penelitian dikembangkan mengacu pada penelitian sebelumnya yang telah dilakukan oleh Widiharto (2008) yang melakukan penelitian rasio keuangan terhadap prediksi kondisi bermasalah Bank Perkreditan Rakyat di wilayah Jabodetabek. Hasil penelitian Widiharto menemukan bahwa Kualitas Aset dan Earning berpengaruh secara signifikan terhadap kondisi bermasalah Bank Perkreditan Rakyat. Sementar itu penelitian Luciana dan Winny (2005), Christian (2008) tentang rasio-rasio keuangan sebagai indikator dalam memprediksi potensi kondisi bermasalah, hasil keduanya tidak terdapat perbedaan yang mencolok, dimana pada prinsipnya bahwa pihak BPR perlu memberikan perhatian khusus terhadap likuiditas dan rasio aktiva produktif bermasalah serta dalam rangka menghindari kondisi bermasalah. Namun dari hasil penelitian sebelumnya yang dilakukan oleh Tarmizi dan Willyanto (2003) dengan Sugiyanto et al. (2002) terdapat perbedaan. Menurut Tarmizi dan Willyanto (2003) pada periode satu tahun sebelum kondisi bermasalah, komponen kualitas aset, manajemen dan likuiditas tidak memiliki pengaruh terhadap 
prediksi kondisi bermasalah bank untuk satu tahun yang akan datang. Sedangkan penelitian yang dilakukan Sugiyanto et al. (2002) menyatakan bahwa komponen kualitas aset, manajemen, earning power dan likuiditas memiliki pengaruh terhadap prediksi kondisi bermasalah bank untuk satu tahun yang akan datang.

\section{B. KAJIAN PUSTAKA}

Kajian teori yang mendasari penelitian ini meliputi: Rasio Keuangan; Analisis Rasio CAMEL; dan Kondisi BPR bermasalah.

\section{Rasio Keuangan}

Rasio keuangan adalah bentuk hubungan antara dua data keuangan yang dinyatakan dalam perbandingan matematis. Rasio keuangan bertujuan untuk menyederhanakan informasi yang menggambarkan hubungan antara pos tertentu dengan pos lainnya yang mempunyai hubungan relevan dan signifikan (Harahap, 1999). Rasio keuangan merupakan instrumen analisis prestasi perusahaan yang menjelaskan berbagai hubungan dan indikator keuangan, yang ditujukan untuk menunjukkan perubahan dalam kondisi keuangan atau prestasi operasi di masa lalu dan membantu menggambarkan trend pola perubahan tersebut, untuk kemudian menunjukkan resiko dan peluang yang melekat pada perusahaan yang bersangkutan (Helfert, 1991).

Namun demikian analisis rasio keuangan juga memiliki keterbatasan yang perlu diperhatikan pada saat digunakan. Keterbatasan tersebut antara lain: (1) Kesulitan dalam memilih rasio yang tepat dan dapat digunakan untuk kepentingan pemakainya; (2) Keterbatasan yang dimiliki akuntansi atau laporan keuangan juga menjadi keterbatasan dalam menggunakan rasio; (3) Tidak tersedianya data untuk menghitung rasio dan (4) Perbedaan teknik atau standar akuntansi yang digunakan dari setiap perusahaan yang akan dianalisis.

\section{Rasio CAMEL}

Rasio keuangan perbankan dapat diidentifikasikan dengan menggunakan unsur Capital, Assets quality, Management, Earnings dan Liquidity (CAMEL). Pemanfaatan rasio keuangan dalam menilai kondisi keuangan telah diterapkan oleh Bank Indonesia dalam menilai tingkat kesehatan bank sebagaimana dituangkan dalam Surat Keputusan Direksi Bank Indonesia No. 30/12/KEP/DIR tentang Tatacara Penilaian Tingkat Kesehatan Bank Perkreditan Rakyat dan Surat Edaran Bank Indonesia No. 30/3/UPPB tentang Tatacara Penilaian Tingkat Kesehatan Bank Perkreditan Rakyat (BI, 1997). Alat analisis yang digunakan untuk mengukur kinerja tersebut bersumber dari indikator CAMEL.

\section{a. CAMEL Rating System}

Bank dikatakan sehat (tidak bermasalah) apabila indikator-indikator yang menunjukkan kinerja suatu bank menunjukkan nilai yang baik. Berdasarkan Surat Edaran Bank Indonesia Nomor 30/3/UPPB tanggal 30 April 1997 tentang Tata Cara Penilaian Tingkat Kesehatan Bank Perkreditan Rakyat, penilaian tingkat kesehatan dilakukan dengan melihat faktor faktor: Capital (Permodalan), Asset quality (Kualitas Aset), Management (Manajemen), Earnings (Kemampuan mencetak laba) dan Liquidity (Likuiditas) atau biasa disingkat dengan CAMEL.

\section{b. Rasio CAMEL}

Dalam kamus Perbankan (Institut Bankir Indonesia, 1999), CAMEL adalah aspek yang paling banyak berpengaruh terhadap kondisi keuangan bank. Perumusan faktor-faktor CAMEL yang dimaksud seperti berikut.

1) Aspek Permodalan: Penilaian aspek permodalan bank lebih dimaksudkan untuk mengetahui bagaimana atau berapa modal bank tersebut telah memadai untuk menunjang kebutuhannya. Kecukupan modal dalam model CAMEL dihitung dengan menggunakan rasio CAR (Capital Adequacy Ratio) berikut ini. 
$\mathrm{CAR}=\frac{\text { MODALBANK }}{\text { AKTIVATERTIMBANGMENURUT RISIKO }}$

(SEBI No. 8/18/PBI/2006)

2) Aspek Kualitas Aset: Menunjukkan kualitas aset sehubungan dengan risiko kredit yang dihadapi bank akibat pemberian kredit dan investasi dana bank pada portofolio yang berbeda. Penilaian didasarkan dua rasio berikut ini.

$$
\text { KUALITASAKTIVA-1 }=\frac{\text { AKTIVA PRODUKTIF BERMASALAH }}{\text { TOTAL AKTIVA PRODUKTIF }}
$$

(SEBI No. 30/33/UPPB/4. 1997)

$$
\text { KUALITAS AKTIVA-2 }=\frac{\text { PPAP YANG DIBENTUK }}{\text { TOTAL AKTIVA PRODUKTIF }}
$$

(SEBI No. 30/33/UPPB/4. 1997)

3) Aspek Manajemen: Aspek ini diartikan sebagai kemampuan manajemen perusahaan perbankan dalam mengendalikan operasinya ke dalam maupun keluar. Aspek manajemen dalam penelitian ini dinilai berdasarkan rasio laba bersih terhadap pendapatan operasi (profit margin).

$$
\text { PROFIT MARGIN }=\frac{\text { LABA BERSIH }}{\text { PENDAPATANOPERASI }}
$$

(PBI No. 8/18/PBI/2006)

4) Aspek Earnings: Analisis rentabilitas dimaksudkan untuk mengukur kemampuan bank untuk menetapkan harga yang mampu menutup seluruh biaya. Laba memungkinkan bank untuk bertumbuh. Laba yang dihasilkan secara stabil akan memberikan nilai tambah. Aspek rentabilitas dalam penelitian ini dinilai berdasarkan dua rasio yakni rasio laba sebelum pajak terhadap total aktiva (ROA).

$$
\text { ROA }=\frac{\text { LABA SEBELUM PAJAK }}{\text { TOTAL AKTIVA }}
$$

(SEBI No. 30/33/UPPB/4. 1997)

5) Aspek Likuiditas: Analisis likuiditas dimaksudkan untuk mengukur seberapa besar kemampuan bank tersebut mampu membayar utang-utangnya dan membayar kembali kepada deposannya serta dapat memenuhi permintaan kredit yang diajukannya tanpa terjadi penangguhan. Penilaian aspek likuiditas ini didasarkan pada rasio kredit terhadap dana yang diterima (BI, 1997). Aspek ini dinilai berdasarkan rasio Loan to Deposit Ratio (LDR) berikut ini.

$$
\text { LDR } \frac{\text { TOTAL KREDIT }}{\text { DANA PIIAK KETIGA }}
$$

(SEBI No. 30/33/UPPB/4. 1997) 


\section{Kondisi Bermasalah}

Supardi dan Sri Mastuti

(2003)

menyatakan bahwa manajemen cukup sering mengalami kegagalan dalam membesarkan perusahaan. Akibatnya, prospek perusahaan menjadi tidak sehat (bermasalah). Pada situasi demikian, pemilik dan manajemen berusaha keras memutar arah organisasi. Kondisi bermasalah dapat mengarah pada kebangkrutan (bankruptcy).

Luciana dan Winny (2005) meneliti rasio CAMEL terhadap kondisi bermasalah lembaga perbankan. Penelitiannya menghasilkan bahwa dari 11 rasio keuangan CAMEL yang digunakan yaitu CAR, ATTM, APB, NPL, PPAP, ROA, ROE, NIM, BOPO, LDR, adalah rasio-rasio yang memiliki perbedaan signifikan antara bank-bank kategori bermasalah dan tidak bermasalah periode 2000-2002. Hasil penelitiannya menghasilkan kesimpulan bahwa rasio yang berpengaruh signifikan terhadap prediksi kondisi bermasalah bank-bank swasta nasional di Indonesia adalah rasio CAR dan BOPO.

Sugiyanto et al. (2002) yang menggunakan variabel Permodalan, Kualitas Aset, Manajemen, Earning Power dan Likuiditas mengatakan bahwa kekuatan permodalan tidak memiliki hubungan terhadap prediksi kondisi bermasalah bank untuk satu tahun maupun dua tahun yang akan datang, sedangkan kualitas aset, manajemen, earning power dan likuiditas memiliki hubungan terhadap prediksi kondisi bermasalah bank untuk satu tahun maupun dua tahun yang akan datang.

Indira (2002) dalam penelitiannya menyatakan bahwa kekuatan dalam ketepatan memprediksi cenderung meningkat dari dua ke satu tahun sebelum bangkrut untuk kondisi bermasalah 1997.

Berdasarkan atas penjelasan tersebut diatas, selanjutnya indikator dari sinyal kondisi bermasalah BPR Konvensional yang ada di wilayah Yogyakarta adalah:

- BPR Konvensional yang mengalami kerugian triwulanan dan atau berturut-turut sejak Triwulan II/2011 s/d Triwulan II/2012.

- BPR Konvensional yang memiliki CAR kurang dari 4\% (BI, 1997).

- BPR Konvensional yang memiliki NPL diatas persyaratan Bank Indonesia yaitu lebih dari $5 \%$.

Data penelitian ini menggunakan laporan keuangan triwulanan merujuk pada hasil penelitian Indira (2002), dimana kekuatan memprediksi cenderung meningkat dalam jangka waktu yang lebih pendek.

\section{KERANGKA PIKIR DAN PENGEMBANGAN HIPOTESIS}

Berdasarkan kajian teoritis dan penelitian yang berkembang, selanjutnya Kerangka Pikir dapat digambarkan dalam skema berikut ini.

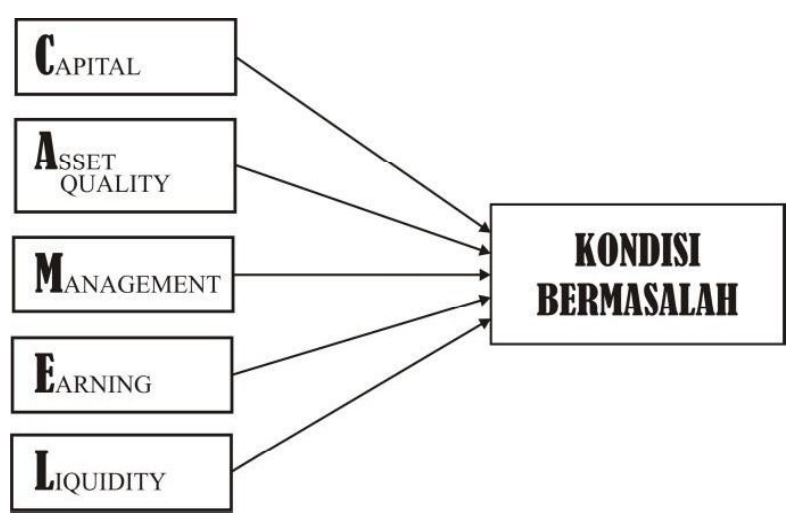

Gambar 1: Kerangka Pikir

Berdasarkan kerangka tersebut, maka hipotesis yang dikembangkan sebagai berikut:

\section{Pengaruh Capital Adequacy Ratio terhadap Kondisi Bermasalah \\ Bank Indonesia (2006) menyatakan} bahwa permodalan berpengaruh negatif terhadap kondisi bermasalah. Hal ini didukung oleh Luciana dan Winny (2005) dari hasil penelitiannya menemukan bahwa rasio CAR berpengaruh negatif, artinya semakin rendah rasio ini maka semakin besar kemungkinan suatu bank dalam kondisi bermasalah, diketahui juga bahwa pengaruh rasio CAR terhadap kondisi bermasalah adalah signifikan. Dengan pengertian lain bahwa CAR berpotensi sebagai indikator sinyal kondisi bermasalah. 
Atas dasar hal tersebut, maka hipotesis yang dikembangkan yaitu:

H1: Rasio CAR berpengaruh negatif terhadap kondisi bermasalah

\section{- Pengaruh Assets Quality Terhadap Kondisi Bermasalah}

Hasil penelitian sebelumnya yang dilakukan oleh Luciana dan Winny (2005) menyatakan bahwa rasio Aktiva Produktif Bermasalah (NPL) berpengaruh terhadap kondisi bermasalah, tetapi tidak signifikan. Sedangkan rasio PPAP terhadap Aktiva Produktif mempunyai pengaruh positif tetapi tidak signifikan, artinya semakin tinggi rasio ini maka semakin besar kemungkinan suatu bank dalam kondisi bermasalah. Sugiyanto et al. menyatakan bahwa kondisi bermasalah suatu bank secara nyata tergantung oleh Kualitas Aset suatu bank. Hasil penelitian di atas mendukung Bank Indonesia (2006) yang menyatakan bahwa Asset Quality berpengaruh positif terhadap kondisi bermasalah. Dengan pengertian lain bahwa NPL \& PPAP sebagai factor kualitas aset berpotensi sebagai indikator sinyal kondisi bermasalah. Atas dasar hal tersebut, maka hipotesis yang dikembangkan yaitu:

H2a: Rasio aktiva produktif bermasalah terhadap total aktiva produktif berpengaruh terhadap kondisi bermasalah.

H2b: Rasio PPAP yang telah dibentuk terhadap total aktiva produktif berpengaruh terhadap kondisi bermasalah.

\section{- Pengaruh Management Terhadap Kondisi Bermasalah}

Bank Indonesia (2006) menyatakan bahwa aspek manajemen yang di proksi dengan Profit Margin berpengaruh negatif terhadap kondisi bermasalah. Hasil penelitian Sugiyanto et al. (2002) menemukan bahwa komponen manajemen yang diproksi dengan profit margin menunjukkan pengaruh negatif terhadap kondisi bermasalah suatu bank. Artinya semakin rendah profit margin menyababkan prediksi kondisi bermasalah semakin tinggi. Dengan pengertian lain bahwa Profit Margin berpotensi sebagai indikator sinyal kondisi bermasalah. Atas dasar hal tersebut, maka hipotesis yang dikembangkan yaitu:

H3: Profit margin berpengaruh negatif terhadap prediksi kondisi bermasalah.

\section{Pengaruh Earnings Terhadap Kondisi Bermasalah}

Secara teoritis ROA berpengaruh negatif terhadap prediksi kondisi bermasalah, artinya semakin rendah rasio ini maka semakin besar kemungkinan suatu bank dalam kondisi bermasalah. Walaupun penelitian sebelumnya menemukan pengaruh yang tidak signifikan seperti yang telah ditemukan oleh Luciana dan Winny (2005). Dengan pengertian lain bahwa ROA berpotensi sebagai indikator sinyal kondisi bermasalah. Atas dasar hal tersebut, maka hipotesis yang dikembangkan yaitu:

H4: ROA berpengaruh negatif terhadap prediksi kondisi bermasalah

\section{Pengaruh Liquidity Terhadap \\ Kondisi Bermasalah \\ Hasil penelitian Tarmizi dan Willyanto} (2003) menemukan bahwa komponen likuiditas untuk periode satu tahun tidak memiliki pengaruh terhadap prediksi kondisi bermasalah. Sementara itu, menurut Sugiyanto et al. (2002) komponen likuiditas memiliki pengaruh terhadap kondisi bermasalah suatu bank. Aspek likuiditas dalam penelitian ini diukur melalui Loan to Deposit ratio (LDR) yang merupakan perbandingan antara total kredit dengan dana pihak ketiga. Dengan pengertian lain bahwa LDR berpotensi sebagai indikator sinyal kondisi bermasalah. Atas dasar hal tersebut, maka hipotesis yang dikembangkan yaitu:

H5: LDR berpengaruh terhadap prediksi kondisi bermasalah 


\section{METODE PENELITIAN}

Populasi yang menjadi jangkauan penelitian ini adalah BPR yang berada di wilayah Daerah Istimewa Yogyakarta (DIY). Pemilihan ini didasari pertimbangan bahwa di wilayah tersebut terdapat banyak BPR yang tersebar di kabupaten dan kota dan di ibu kota propinsi, dengan modal relatif kecil sampai yang bermodal besar. Dengan demikian hasil penelitian ini diharapkan dapat mencerminkan kondisi BPR secara menyeluruh. Dari populasi sebanyak 54 BPR di wilayah DIY, ditentukan sampel penelitian secara sensus.

\section{Variabel Penelitian dan Difinisi Operasional}

Variabel Penelitian beserta difinisi operasional dan perumusannya seperti nampak pada tabel berikut ini.

Tabel 1: Kisi-Kisi Variabel Penelitian

\begin{tabular}{|c|c|c|c|}
\hline ASPEK & VARIABEL & DEFINISI & RUMUS/PROKSI \\
\hline & CAR & $\begin{array}{l}\text { CAR menunjukkan kemampuan } \\
\text { permodalan bank, atau dapat diartikan } \\
\text { sejauh mana penurunan Asset Bank masih } \\
\text { dapat ditutup oleh Equity bank yang } \\
\text { tersedia, semakin tinggi CAR semakin } \\
\text { baik kondisi sebuah bank. }\end{array}$ & $\begin{array}{c}\text { CAR }-\frac{\text { MODALBANK }}{\text { AKTIVATERTIMBANG MENURUT RISIKO }} \\
\text { (PBI No. 8/18/PBI/2006). }\end{array}$ \\
\hline & $\begin{array}{l}\text { KUALITAS } \\
\text { AKTIVA-1 }\end{array}$ & $\begin{array}{l}\text { Menunjukkan seberapa besar porsi Aktiva } \\
\text { Produktif Bermasalah terhadap Total Aktiva } \\
\text { Produktif (NPL). }\end{array}$ & KUALITAS AKTIVA $-1=\frac{\text { AKTIVA PRODUKTIF BERMASALAH }}{\text { TOTAL AKTIVA PRODUKTIF }}$ \\
\hline & $\begin{array}{l}\text { KUALITAS } \\
\text { AKTIVA-2 }\end{array}$ & $\begin{array}{l}\text { Menunjukkan besarnya Penyisihan } \\
\text { Penghapusan Aktiva Produktif } \\
\text { (PPAP) yang dibentuk terhadap } \\
\text { Total Aktiva Produktif. }\end{array}$ & KUALITAS AKTIVA $-2=\frac{\text { PPAP YANG DIBENTUK }}{\text { TOTAL AKTIVA PRODUKTIF }}$ \\
\hline & $\begin{array}{l}\text { PROFIT } \\
\text { MARGIN }\end{array}$ & $\begin{array}{l}\text { Menunjukkan persentase laba bersih yang } \\
\text { diperoleh terhadap pendapatan operasi. }\end{array}$ & PROFIT MARGIN $=\frac{\text { LABA BERSIH }}{\text { PENDAPATANOPERASI }}$ \\
\hline & ROA & $\begin{array}{l}\text { ROA merupakan kemampuan dari } \\
\text { modal yang diinvestasikan ke dalam } \\
\text { seluruh aktiva perusahaan untuk } \\
\text { menghasilkan keuntungan. ROA } \\
\text { menggunakan laba sebagai salah satu cara } \\
\text { untuk menilai efektivitas dalam } \\
\text { penggunaan aktiva perusahaan dalam } \\
\text { menghasilkan laba. Semakin tinggi laba } \\
\text { yang dihasilkan, maka semakin tinggi } \\
\text { pula ROA }\end{array}$ & $\begin{aligned} \text { ROA }= & \frac{\text { LABA SEBELUM PAJAK }}{\text { RATA - RATA TOTAL ASET }} \\
& (\text { SEBI No: } 6 / 23 / \mathrm{DPNP})\end{aligned}$ \\
\hline & $\begin{array}{l}\text { LDR } \\
\text { (Eksogen) }\end{array}$ & $\begin{array}{l}\text { LDR menyatakan seberapa jauh } \\
\text { kemampuan bank dalam membayar } \\
\text { kembali penarikan dana yang dilakukan } \\
\text { deposan dengan mengandalkan } \\
\text { kredit yang diberikan sebagai } \\
\text { sumber likuiditasnya }\end{array}$ & $\begin{aligned} \text { LDR }= & \frac{\text { TOTAL KREDIT }}{\text { TOTAL DANA PIHAK KETIGA }} \\
& (\text { SEBI No: } 7 / 10 / \text { DPNP })\end{aligned}$ \\
\hline \multicolumn{2}{|c|}{$\begin{array}{c}\text { KONDISI } \\
\text { BERMANALAH }\end{array}$} & $\begin{array}{l}\text { Martin (1995) dalam Supardi dan Sri } \\
\text { Mastuti (2003) menyatakan bahwa kondisi } \\
\text { bermasalah sebagai suatu kegagalan yang } \\
\text { terjadi pada sebuah perusahaan didefinisikan } \\
\text { dalam pengertian kegagalan ekonomi atau } \\
\text { kegagalan keuangan. }\end{array}$ & $\begin{array}{l}\text { 1. BPR Konvensional yang mengalami kerugian } \\
\text { triwulanan dan atau berturut-turut sejak Triwulan } \\
\text { II/2011 s/d Triwulan II/ } 2012 \text {. } \\
\text { 2. BPR Konvensional yang memiliki CAR kurang dari } \\
4 \% \text { (BI, 1997). } \\
\text { 3. BPR Konvensional yang memiliki NPL diatas } \\
\text { persyaratan Bank Indonesia yaitu lebih dari } 5 \% \text {. }\end{array}$ \\
\hline
\end{tabular}

\section{Teknik Analisis}

Teknik analisis yang dilakukan meliputi Uji Asumsi Klasik atau Uji Prasyarat, Analisis Deskriptif, dan Analisis Inferensial.

\section{a. Uji Prasyarat}

Uji asumsi klasik atau uji prasyarat dibutuhkan karena penelitian menggunakan metode parametrik Regresi. Uji asumsi klasik ini meliputi: Uji Normalitas, Uji multikolinearitas, dan Uji Heterokedastisitas, dan Uji Autokorelasi berikut ini. 


\section{b. Analisis Deskriptif}

Analisis deskriptif adalah statistik yang digunakan untuk menganalisa data dengan cara mendiskripsikan atau menggambarkan data yang telah terkumpul sebagaimana adanya tanpa bermaksud membuat kesimpulan yang berlaku untuk digeneralisasikan. Statistik deskriptif dalam penelitian ini disajikan dalam bentuk tabel, grafik, perhitungan mean, nilai minimum dan maksimum.

\section{c. Analisis Inferensial}

Analisis inferensial pada hakekatnya adalah melakukan pengujian terhadap Hipotesis yang dibangun, untuk mengetahui apakah variabel bebas (rasio CAMEL) berpengaruh (menjadi sinyal) terhadap kondisi bermasalah BPR. Untuk melakukan analisis ini, variabel terikatnya merupakan data nominal, maka model analisis yang digunakan adalah model Regression

Logistic (Ghozali, 2002). Regresi logistik digunakan karena lebih baik daripada analisis diskriminan Hair et al. (1995).
Pertama, analisis diskriminan mengandalkan pada ketelitian pertemuan asumsi normalitas multivariat dan kesamaan varian-kovarian matrik semua kelompok, dimana situasi ini sulit ditemukan. Kedua, bahkan jika asumsi ini ditemukan, banyak peneliti lebih menyukai logit analisis karena logit analisis sama dengan regresi dengan uji statistik strightforward, dan metode regresi logistik memiliki kemampuan untuk menggabungkan pengaruh non linear. Regresi logistik sama dengan diskriminan analisis, namun dapat lebih tepat digunakan dalam kondisi-kondisi tertentu, seperti data tidak normal, terdapat multikolinearitas antar variabel independen dan pelanggaran asumsi klasik yang. Untuk melakukan uji pengujian hipotesis ini menggunakan bantuan software Eviews Model umum dari persamaan regresi logistic dengan link function logit seperti berikut ini.

$$
\frac{1}{1-}=\exp \beta_{0}+\beta_{1} X_{j 1}+\beta_{2 X} X+\beta \quad+\beta X_{j}+5 \quad 5+\beta_{j} X \quad j !
$$

Dimana: ${ }_{0}=$ Konstanta; $\beta_{\mathrm{i}}=$ Koefisien; $\mathrm{X}_{\mathrm{i}}=$ Prediktor; $\pi_{\mathrm{j}}=$ Probabilitas covariate ke $-j$ mempunyai response $=1$ (Tidak bermasalah); dari response regresi logistic biner yang mempunyai nilai: $1=$ Kondisi bermasalah; $0=$ Kondisi tidak bermasalah

\section{E. ANALISIS DATA}

Gambaran secara garis besar statistik deskripsi setiap variabel penelitian dari 54
BPR tersebut, seperti terlihat pada tabel dibawah ini.

Tabel 2: Statistik Deskriptif

\begin{tabular}{|ll|l|l|l|l|l|l|}
\hline \multicolumn{2}{|c|}{ SKRIPSI DE } & AR & PL & PAP & M & OA & DR \\
\hline AN ME & & & & & & \\
\hline NIMUM MI & .01 & .29 & .71 & 43.81 & 8.88 & 2.52 \\
\hline XIMUM MA & 6.10 & 9.32 & .73 & 0.91 & .09 & 06.33 \\
\hline $\begin{array}{r}\text { SERVASI OB } \\
\text { SERAS }\end{array}$ & 4 & 4 & 4 & 4 & 4 & 4 \\
\hline
\end{tabular}

Sumber: Data mentah diolah dengan Eviews (terlampir)

Berdasarkan data dan hasil setiap masing-masing variabel independen perhitungan statistik deskriptif tersebut, selanjutnya dapat dilakukan analisis untuk sebagai berikut: 


\section{Capital Adequacy Ratio (CAR)}

Kondisi CAR dari 54 BPR yang ada di wilayah Daerah Istimewa Yogyakarta divisualisasikan pada grafik dibawah ini.

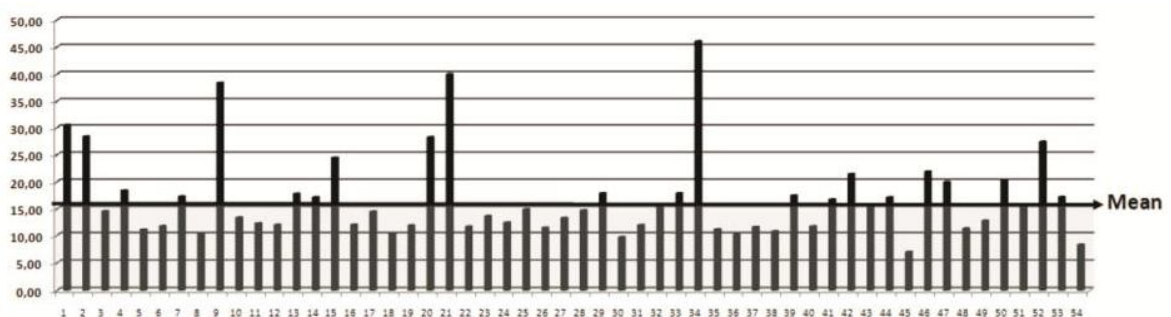

Gambar 2: Grafik CAR

Rata-rata CAR seperti pada Tabel 4.1 tercatat sebesar 16,94\%. Berdasarkan kondisi tersebut, maka dapat diketahui bahwa BPR yang memiliki CAR diatas ratarata sebanyak 21 BPR atau sebesar 38,89\%. Selebihnya 33 BPR atau sebesar 61,11\% memiliki CAR dibawah rata-rata. CAR tertinggi 46,10\% merupakan kinerja PT.
BPR. Nusumma Tempel (Sleman), sedangkan terendah $7,01 \%$ PT. BPR Mataram Mitra Manunggal (Kota Yogya).

\section{Non Performance Loan (NPL)}

Kondisi NPL dari 54 BPR yang ada di wilayah Daerah Istimewa Yogyakarta divisualisasikan pada grafik dibawah ini.

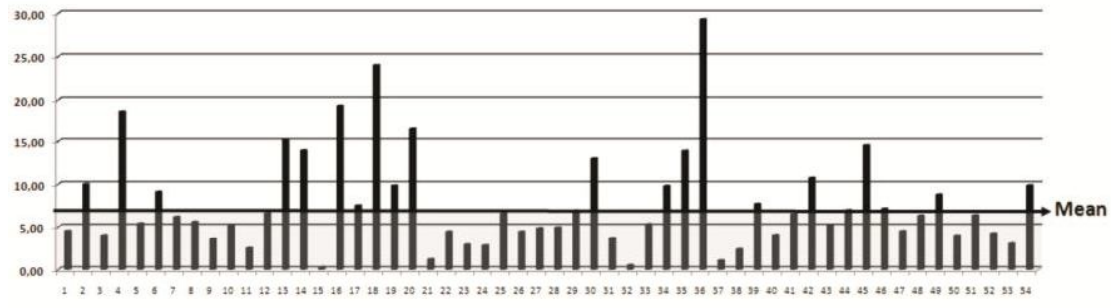

Gambar 3: Grafik NPL

Rata-rata NPL seperti pada Tabel 4.1 tercatat sebesar $7,71 \%$. Berdasarkan kondisi tersebut, maka dapat diketahui bahwa BPR yang memiliki NPL diatas ratarata sebanyak 17 BPR atau sebesar 31,48\%. Selebihnya 37 BPR atau sebesar 68,52\% memiliki NPL dibawah rata-rata. NPL tertinggi 29,32\% merupakan kinerja PT.
BPR. Redjo Bawono (Sleman), sedangkan terendah 0,29\% PT. BPR Bank Sleman (Sleman).

\section{Penyisihan Penghapusan Aktiva produktif (PPAP)}

Kondisi PPAP dari 54 BPR yang ada di wilayah Daerah Istimewa Yogyakarta divisualisasikan pada grafik dibawah ini.

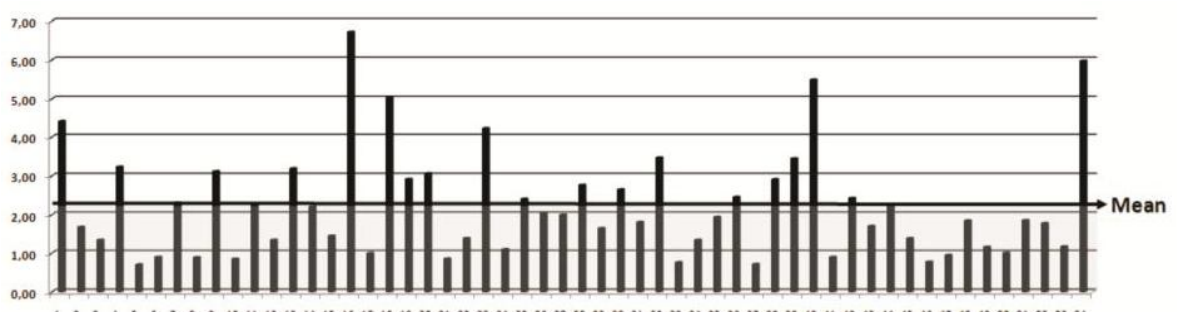

Gambar 4: Grafik PPAP

Rata-rata PPAP seperti pada Tabel 4.1 tercatat sebesar 2,22\%. Berdasarkan kondisi tersebut, maka dapat diketahui bahwa BPR yang memiliki PPAP diatas ratarata sebanyak 22 BPR atau sebesar $40,74 \%$. Selebihnya 32 BPR atau sebesar 59,26\% 
memiliki PPAP dibawah rata-rata. PPAP tertinggi 6,73\% merupakan kinerja PT. BPR. Arto Makmur (Sleman), sedangkan terendah $0,71 \%$ PT. BPR Arta Parama (Bantul).

\section{Profit Margin (PM)}

Kondisi PM dari 54 BPR yang ada di wilayah Daerah Istimewa Yogyakarta divisualisasikan pada grafik dibawah ini

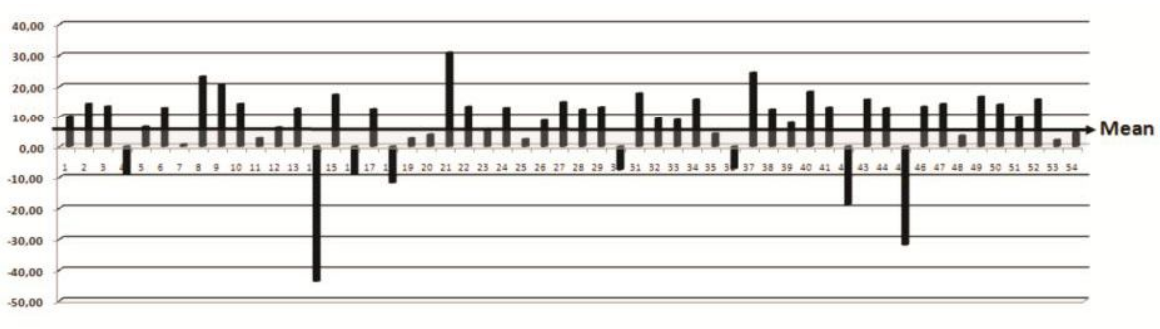

Gambar 5: Grafik PM

Rata-rata PM seperti pada Tabel 4.1 tercatat sebesar 7,52\%. Berdasarkan kondisi tersebut, maka dapat diketahui bahwa BPR yang memiliki PM diatas rata-rata sebanyak 34 BPR atau sebesar $62,96 \%$. Selebihnya 20 BPR atau sebesar $37,04 \%$ memiliki PM dibawah rata-rata. PM tertinggi $30,91 \%$ merupakan kinerja PT. BPR. Artha Mlati
Indah (Sleman), sedangkan terendah 43,81\% PT. BPR Tandu Artha (Bantul).

\section{Return On Assets (ROA)}

Kondisi ROA dari 54 BPR yang ada di wilayah Daerah Istimewa Yogyakarta divisualisasikan pada grafik dibawah ini.

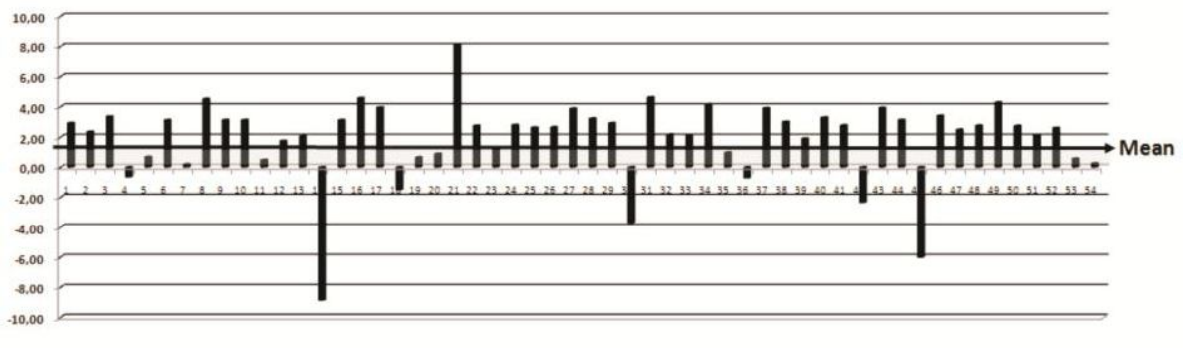

Gambar 6: Grafik ROA

Rata-rata ROA seperti pada Tabel 4.1 tercatat sebesar $1,94 \%$. Berdasarkan kondisi tersebut, maka dapat diketahui bahwa BPR yang memiliki ROA diatas rata6. rata sebanyak 36 BPR atau sebesar $66,67 \%$. Selebihnya 18 BPR atau sebesar 33,33\% memiliki ROA dibawah rata-rata. ROA tertinggi 8,09\% merupakan kinerja PT. BPR. Artha Mlati Indah (Sleman), sedangkan terendah $-8,88 \%$ PT. BPR Tandu Artha (Bantul).

\section{Loan Deposit Ratio (LDR)}

Kondisi LDR divisualisasikan pada grafik dibawah ini.

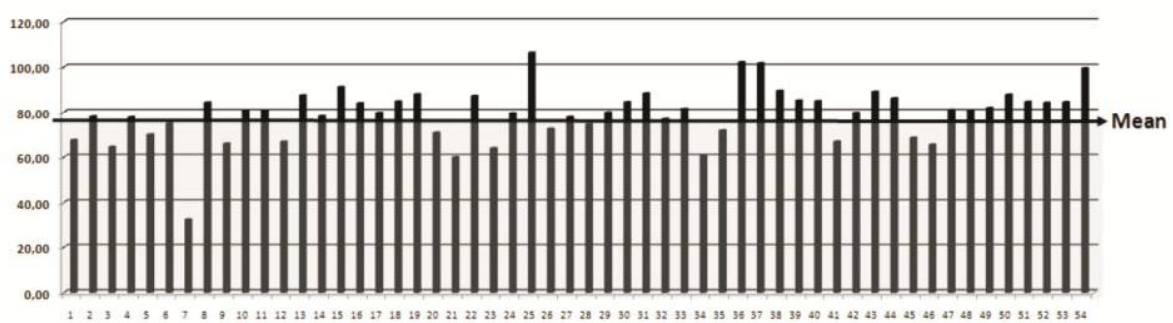

Gambar 7: Grafik LDR

Rata-rata LDR seperti pada Tabel 4.1 tercatat sebesar 79,25\%. Berdasarkan kondisi tersebut, maka dapat diketahui bahwa BPR yang memiliki LDR diatas ratarata sebanyak 32 BPR atau sebesar 59,26\%. Selebihnya 22 BPR atau sebesar 40,74\% 
memiliki LDR dibawah rata-rata. LDR tertinggi 106,33\% merupakan kinerja PT. BPR. Bhumi Karya Pala (Sleman), sedangkan terendah 32,52\% PT. BPR Bina Arta Swadaya (Bantul).

\section{Kond isi Bermasalah}

Sinyal kondisi bermasalah dari BPR yang ada di wilayah Daerah Istimewa Yogyakarta seperti Nampak pada grafik dibawah ini.

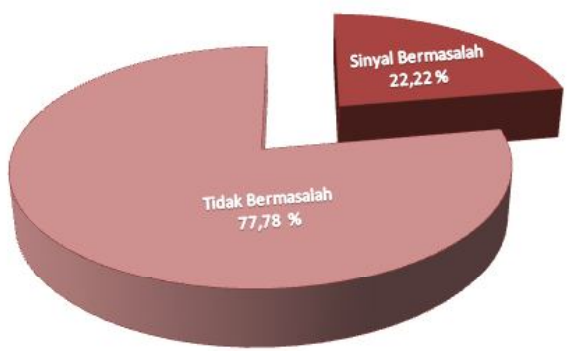

Gambar 8: Grafik Kondisi Bermasalah

Dari 54 BPR yang ada, sebanyak 42 BPR atau sebesar $77,78 \%$ dalam kondisi tidak bermasalah, selebihnya sebanyak 12 BPR atau sebesar 22,22 \% menunjukkan sinyal kondisi bermasalah.

\section{F. Uji Asumsi Klasik}

Penelitian ini menggunakan alat analisis regresi, oleh karena itu memerlukan dipenuhinya berbagai asumsi agar model dapat digunakan sebagai alat prediksi yang baik. Adapun asumsi yang akan diuji meliputi masalah: Normalitas, Multikolinearitas, Heterokedastisitas, dan Autokorelasi.

\section{Uji Normalitas}

Untuk menguji distribusi normalitas data, menggunakan koefisien Jarque-Bera yang diproses dengan software Eviews.
Apabila nilai koefisien Jarque-Bera < $\chi^{2}(0,05 ; n-2)$ maka data berdistribusi normal. Berdasarkan uji normalitas dengan menggunakan output Eviews, diperoleh hasil seperti tabel berikut ini.

\begin{tabular}{l} 
Tabel 3: Hasil Uji Normalitas \\
\begin{tabular}{|c|c|c|}
\hline Variabel & $\begin{array}{c}\text { Koefisien } \\
\text { Jarque-Bera }\end{array}$ & Kondisi \\
\hline CAR & 150,02 & Normal \\
\hline NPL & 78,86 & Normal \\
\hline PPAP & 10,28 & Normal \\
\hline PM & 181,29 & Normal \\
\hline ROA & 290,30 & Normal \\
\hline LDR & 7,79 & Normal \\
\hline
\end{tabular} \\
\hline
\end{tabular}

Dari hasil output pada tabel diatas, dapat disimpulkan bahwa semua variabel penelitian berdistribusi normal, berdasarkan kriteria bahwa koefisien Jarque-Bera dari semua variabel berada dibawah $\chi^{2}$ Tabel sebesar 307,18 $\left({ }^{2}(0,05 ; n=268)\right.$.

Uji Multikolinearitas

Untuk menguji ada tidaknya multikolinearitas, dengan menghitung koefisien korelasi antar variabel independen. Apabila koefisiennya rendah, maka tidak terdapat multikolinearitas (Winarno, 2009). Berdasarkan uji multikolinearitas dengan menggunakan output Eviews, diperoleh hasil matrix korelasi sebagian besar bernilai kecil seperti tabel dibawah ini, meskipun ada beberapa diantaranya yang koefisien korelasinya relative besar namun masih dibawah 0,70 .

Tabel 4: Hasil Uji Multikolinearitas (Matriks Korelasi)

\begin{tabular}{|crrrrrrr||}
\hline & MASALAH & \multicolumn{1}{c}{ CAR } & NPL & PPAP & \multicolumn{1}{c|}{ PM } & \multicolumn{1}{c|}{ ROA } & LDR \\
\hline \hline MASALAH & 1.000000 & -0.052505 & 0.662720 & 0.415725 & -0.157176 & -0.167687 & 0.016905 \\
CAR & -0.052505 & 1.000000 & -0.132647 & -0.028924 & 0.108745 & 0.077850 & -0.246175 \\
NPL & 0.662720 & -0.132647 & 1.000000 & 0.330270 & -0.154411 & -0.141016 & -0.064187 \\
PPAP & 0.415725 & -0.028924 & 0.330270 & 1.000000 & -0.146546 & -0.147188 & 0.149120 \\
PM & -0.157176 & 0.108745 & -0.154411 & -0.146546 & 1.000000 & 0.636407 & 0.017471 \\
ROA & -0.167687 & 0.077850 & -0.141016 & -0.147188 & 0.636407 & 1.000000 & -0.178238 \\
LDR & 0.016905 & -0.246175 & -0.064187 & 0.149120 & 0.017471 & -0.178238 & 1.000000 \\
\hline
\end{tabular}




\section{Uji Heterokedastisitas}

Untuk menguji ada tidaknya masalah heterokedastisitas, dilakukan uji Glejser menggunakan software Eviews. Apabila koefisien variabel independen tidak signifikan atau $t_{\text {hitung }}<t_{\text {tabel }}$, maka dapat disimpulkan tidak ditemukan masalah heterokedastisitas. Nilai $t_{\text {tabel }}$ diperoleh 2,2254 (Prob=0,025 [dua sisi]; $\mathrm{DF}=268$ ). Berdasarkan uji heterokedastisitas menggunakan metode Glejser, diperoleh output Eviews seperti tabel berikut ini.

Tabel 5: Hasil Uji Heterokedastisitas

\begin{tabular}{|c|c|c|}
\hline $\begin{array}{c}\text { Variabel } \\
\text { Dependen }\end{array}$ & $\mathrm{t}_{\text {hitung }}$ & Prob. \\
\hline CAR & 1,3193 & 0,1882 \\
\hline NPL & $-1,3967$ & 0,1637 \\
\hline PPAP & 1,1752 & 0,2409 \\
\hline PM & 0,0925 & 0,9264 \\
\hline ROA & 0,9001 & 0,3689 \\
\hline LDR & $-0,412$ & 0,6790 \\
\hline \multicolumn{2}{|c|}{ Sumber: Output Eviews terlampir } \\
\hline
\end{tabular}

Sebagaimana tabel diatas, semua variabel memiliki $t_{\text {hitung }}<t_{\text {tabel }}(2,2696)$, oleh karena itu dapat diduga antarvariabel independen tidak terjadi persoalan heterokedastisitas.

\section{Uji Autokorelasi}

Untuk mengetahui ada tidaknya autokorelasi, metode pengujian yang digunakan adalah Uji Durbin-Watson dengan ketentuan: a. Jika DW lebih kecil dari dL atau lebih besar dari (4-dL), maka dalam hal ini terjadi autokorelasi.

b. Jika DW terletak antara dU dan (4dU), artinya tidak terjadi autokorelasi

c. Jika DW terletak antara dL dan dU atau diantara (4-dU) dan (4-dL), artinya tidak menghasilkan kesimpulan yang pasti.

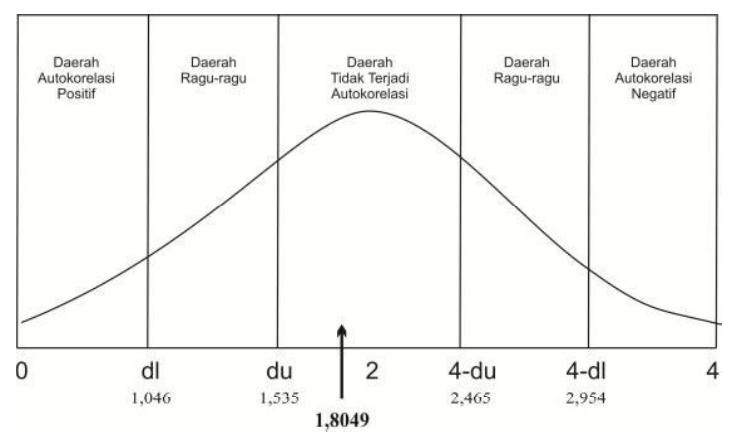

Gambar 9: Daerah Penerimaan Uji Durbin Watson

Selanjutnya berdasarkan gambar diatas, maka menghasilkan kesimpulan tidak tidak terjadi autokorelasi.

\section{G. Uji Hipotesis}

Uji hipotesis dilakukan dengan model regression Logistic menggunakan bantuan software Eviews 6. Berdasarkan output Eviews, diperoleh hasil seperti tabel berikut ini.

Tabel 6: Uji Hipotesis

\begin{tabular}{|l|c|c|c|c|}
\hline \multicolumn{1}{|c|}{ Hipotesis } & Coefficient & Z-Statistik & Prob. & Hasil \\
\hline H1: Pengaruh CAR Terhadap Masalah & $-1,4373$ & $-5,4477$ & 0,0000 & Terbukti \\
\hline H2a: Pengaruh NPL Terhadap Masalah & 5,7285 & 6,3545 & 0,0000 & Terbukti \\
\hline H2b: Pengaruh PPAP Terhadap Masalah & 1,1913 & 3,6966 & 0,0002 & Terbukti \\
\hline H3: Pengaruh PM Terhadap Masalah & $-0,5012$ & $-1,3183$ & 0,1874 & Tidak \\
\hline H4: Pengaruh ROA Terhadap Masalah & 0,0577 & 0,1402 & 0,8884 & Tidak \\
\hline H5: Pengaruh LDR Terhadap Masalah & $-1,5243$ & $-4,3700$ & 0,0000 & Terbukti \\
\hline
\end{tabular}

Berdasarkan tabel 4.6 diatas, selanjutnya dapat dijelaskan Potensi Rasio Keuangan CAMEL sebagai indikator sinyal kondisi bermasalah BPR di wilayah Daerah Istimewa Yogyakarta, sebagai berikut ini.

\section{Pengaruh CAR Terhadap Sinyal Kondisi Bermasalah}

Pengaruh Capital Adecuacy Ratio (CAR) terhadap sinyal kondisi bermasalah
Bank Perkreditan Rakyat di wilayah Daerah Istimewa Yogyakarta, berdasarkan Tabel 4.6 diatas dapat diketahui bahwa rasio CAR tiga bulan sebelumnya berpengaruh secara signifikan terhadap sinyal kondisi 
bermasalah pada Bank Perkreditan Rakyat di DIY. Hal ini ditunjukkan oleh Prob. 0,0000 lebih kecil dari $\alpha=0,05$. Dengan demikian dapat dikemukakan bahwa semakin rendah rasio CAR maka semakin tinggi sinyal potensi Bank Perkreditan Rakyat berada dalam kondisi bermasalah, sebaliknya semakin tinggi CAR, maka potensi kondisi bermasalah semakin rendah.

\section{Pengaruh NPL Terhadap Sinyal Kondisi Bermasalah}

Pengaruh Non Performance Loan Ratio (NPL) terhadap sinyal kondisi bermasalah Bank Perkreditan Rakyat di wilayah Daerah Istimewa Yogyakarta, berdasarkan Tabel 4.6 diatas dapat diketahui bahwa NPL tiga bulan sebelumnya berpengaruh secara signifikan terhadap sinyal kondisi bermasalah pada Bank Perkreditan Rakyat di DIY. Hal ini ditunjukkan oleh Prob. 0,0000 lebih kecil dari $a=0,05$. Dengan demikian dapat dikemukakan bahwa semakin rendah rasio NPL maka semakin rendah sinyal potensi Bank Perkreditan Rakyat berada dalam kondisi bermasalah, sebaliknya semakin tinggi NPL, maka potensi kondisi bermasalah juga semakin tinggi.

\section{Pengaruh PPAP Terhadap Sinyal Kondisi Bermasalah}

Pengaruh Penyisihan Penghapusan Aktiva produktif (PPAP) terhadap sinyal kondisi bermasalah Bank Perkreditan Rakyat di wilayah Daerah Istimewa Yogyakarta, berdasarkan Tabel 4.6 diatas dapat diketahui bahwa PPAP tiga bulan sebelumnya berpengaruh secara signifikan terhadap sinyal kondisi bermasalah pada Bank Perkreditan Rakyat di DIY. Hal ini ditunjukkan oleh Prob. 0,0000 lebih kecil dari $a=0,05$. Dengan demikian dapat dikemukakan bahwa semakin rendah rasio PPAP maka semakin rendah sinyal potensi Bank Perkreditan Rakyat berada dalam kondisi bermasalah, sebaliknya semakin tinggi PPAP, maka potensi kondisi bermasalah juga semakin tinggi.

\section{Pengaruh PM Terhadap Sinyal Kondisi Bermasalah}

Pengaruh Profit Margin (PM) terhadap sinyal kondisi bermasalah Bank Perkreditan Rakyat di wilayah Daerah Istimewa Yogyakarta, berdasarkan Tabel 4.6 diatas dapat diketahui bahwa PM tiga bulan sebelumnya tidak berpengaruh secara signifikan terhadap sinyal kondisi bermasalah pada Bank Perkreditan Rakyat di DIY. Hal ini ditunjukkan oleh Prob. 0,1874 lebih besar dari $\alpha=0,05$.

\section{Pengaruh ROA Terhadap Sinyal Kondisi Bermasalah \\ Pengaruh Return On Assets (ROA)} terhadap sinyal kondisi bermasalah Bank Perkreditan Rakyat di wilayah Daerah Istimewa Yogyakarta, berdasarkan Tabel 4.6 diatas dapat diketahui bahwa ROA tiga bulan sebelumnya tidak berpengaruh secara signifikan terhadap sinyal kondisi bermasalah pada Bank Perkreditan Rakyat di DIY. Hal ini ditunjukkan oleh Prob. 0,8884 Prob. 0,0000

\section{Pengaruh LDR Terhadap Sinyal Kondisi Bermasalah}

Pengaruh Loan to Deposit Ratio (LDR) terhadap sinyal kondisi bermasalah Bank Perkreditan Rakyat di wilayah Daerah Istimewa Yogyakarta, berdasarkan Tabel 4.6 diatas dapat diketahui bahwa LDR tiga bulan sebelumnya berpengaruh secara signifikan terhadap sinyal kondisi bermasalah pada Bank Perkreditan Rakyat di DIY. Hal ini ditunjukkan oleh Prob. 0,0000. Dengan demikian dapat dikemukakan bahwa semakin rendah rasio LDR maka semakin tinggi sinyal potensi Bank Perkreditan Rakyat berada dalam kondisi bermasalah, sebaliknya semakin tinggi LDR, maka potensi kondisi bermasalah semakin rendah.

\section{H. PEMBAHASAN}

Model sinyal kondisi bermasalah perlu dikembangkan, karena dengan mengetahui adanya sinyal tersebut, sejak dini diharapkan dapat melakukan tindakan untuk mengantisipasi. Sinyak kondisi 
bermasalah ini akan menjadi perhatian berbagai pihak, antara lain: (1). Pemberi pinjaman, terkait mengambil kebijakan memberikan suatu pinjaman serta pengawasan terhadap pinjaman yang diberikan : (2). Investor, terkait menilai kemungkinan masalah yang dihadapi bank dalam mendapatkan return; (3). Lembaga regulator, terkait pembuatan kebijakan dan kepatuhan bank melaksanakan peraturan perundangan; (4). Pemerintah, terkait berbagai regulasi yang melindungi berbagai pihak dari kemungkinan dirugikan; (5) Auditor, terkait penilaian going concern; (6). Manajemen, terkait supervisi operasional bank agar tidak terjadi masalah.

\section{Pengaruh CAR Terhadap Sinyal Kondisi Bermasalah}

Hasil penelitian ini menunjukkan bahwa rasio keuangan CAR yang merupakan proksi faktor asset berpotensi sebagai indikator sinyal kondisi bermasalah Bank Perkreditan Rakyat di wilayah Daerah Istimewa Yogyakarta. Dalam menganalisis suatu bank, pada umumnya perhatian difokuskan pada kecukupan modal bank karena masalah solvensi. Namun demikian, menganalisis aktiva produktif secara cermat tidak kalah pentingnya. Pada kondisi normal, aktiva bank terdiri dari kredit dan aktiva lain yang menghasilkan sumber pendapatan bank, oleh sebab itu dikatakan sebagai aktiva produktif. Kualitas aktiva produktif bank yang sangat jelek akan dapat menghapus modal bank. Modal merupakan salah satu faktor penting dalam rangka pengembangan usaha bisnis dan menampung resiko kerugian, semakin tinggi CAR maka semakin kuat kemampuan bank tersebut utnuk menanggung resiko dari setiap kredit/aktiva produktif yang berisiko. Jika nilai CAR tinggi (sesuai ketentuan BI 8\%) berarti bank tersebut mampu membiayai operasi bank, keadaan yang menguntungkan bank tersebut akan memberikan kontribusi yang cukup besar bagi profitabilitas (Mudrajad Kuncoro dan Suhardjono: 2002).

\section{Pengaruh NPL Terhadap Sinyal Kondisi MASALAH}

Tingginya NPL menjadi sinyal kondisi bermasalah. Seperti terlihat pada analisis deskriptif, rata-rata NPL BPR di DIY tercatat sebesar $7,71 \%$, dimana $31,48 \%$ berada diatas rata-rata. Tingginya NPL ini, jika tidak dapat tertagih akan mengurangi nilai aktiva, dan jika hal tersebut berlanjut maka akan mengurangi modal bank. NPL adalah tingkat pengembalian kredit yang diberikan deposan kepada bank, atau dengan kata lain NPL merupakan tingkat kredit macet pada bank tersebut. Semakin rendah NPL maka bank tersebut akan semakin mengalami keuntungan, sebaliknya bila tingkat NPL tinggi bank tersebut akan mengalami kerugian yang diakibatkan tingkat pengembalian kredit macet.

\section{Pengaruh PPAP Terhadap Sinyal Kondisi MASALAH \\ Penurunan kualitas aktiva} menyebabkan peningkatan cadangan penyisihan penghapusan aktiva produktif. Penurunan tersebut juga dapat menyebabkan menurunnya rasio modal terhadap aktiva menurut resiko, dan semakin menurunnya aktiva menyebabkan bobot resiko akan semakin besar sehingga modal minimal yang harus disediakan juga semakin besar. Semakin menurunnya aktiva menyebabkan persentase cadangan penyisihan penghapusan aktiva produktif yang harus dipenuhi semakin besar. Hasil tersebut menyebabkan semakin meningkatnya biaya operasional untuk penurunan atas aktiva produktif termasuk biaya penghapusan piutang tak tertagih atau kredit macet. Oleh karena itu, Bank Perkreditan Rakyat harus dapat mengendalikan aktiva produktifnya semaksimal mungkin.

\section{Pengaruh PM Terhadap Sinyal Kondisi MASALAH}

Laba bank jika dikaitkan dengan faktor permodalan, semakin tinggi laba BPR makin besar kewajiban penyediaan modal minimal karena laba ditahan dan laba tahun 
berjalan merupakan komponen modal yang digunakan untuk menghitung angka kewajiban modal minimum. Laba berhubungan dengan biaya yang digunakan untuk mendapatkan pendapatan operasional. Untuk mempertahankan kesehatan bank, sudah barang tentu perlu adanya perbaikan manajemen untuk meningkatkan laba bank. Apabila bank mengalami kerugian, tentu saja secara bertahap akan mengurangi modalnya.

\section{Pengaruh ROA Terhadap Sinyal Kondisi} MASALAH

Laba bank jika dikaitkan dengan faktor permodalan bahwa semakin tinggi laba BPR makin besar kewajiban penyediaan modal minimal karena laba ditahan dan laba tahun berjalan merupakan komponen modal. yang digunakan untuk menghitung angka kewajiban modal minimum. Laba berhubungan dengan biaya yang digunakan untuk mendapatkan pendapatan operasional. Untuk mempertahankan kesehatan bank, sudah barang tentu perlu adanya perbaikak manajemen untuk meningkatkan laba bank. Apabila bank mengalami kerugian, tentu saja secara bertahap akan mengurangi modalnya.

\section{Pengaruh LDR Terhadap Sinyal Kondisi MASALAH

c.

LDR terbukti berpengaruh terhadap sinyal bermasalah, hal ini dikarenakan tingginya loan yang diberikan oleh bank dibandingkan dengan dana yang diterima dari nasabah. Seperti Nampak pada analisi deskriptif, rata-rata LDR 79,25\%. Artinya dana pihak ketiga dapat dioptimalisasikał secara maksimal. Kondisi ini memang akan mendorong meningkatnya keuntungan bank, namun disisi lain mengandung risiko yang cukup tinggi terutama dikaitkan dengan kredit macet. LDR ditentukkan oleh perbandingan antara jumlah pinjaman yang. diberikan dengan dana masyarakat yang dihimpun yaitu mencakup giro, simpanan berjangka (deposito), dan tabungan. LDR tersebut menyatakan seberapa jauh kemampuan bank dalam membayar kembali penarikan dana yang dilakukan deposah dengan mengandalkan kredit yang diberikan sebagai sumber likuiditasnya. Semakin besar kredit maka pendapatan yang diperoleh naik, karena pendapatan naik secara otomatis laba juga akan mengalami kenaikan.

\section{SIMPULAN DAN IMPLIKASI HASIL PENELITIAN}

Simpulan dan implikasi hasil dari penelitian ini dapat disampaikan sebagai berikut:

\section{Simpulan}

Berdasarkan hasil penelitian untuk mengetahui pengaruh (potensi) rasio CAMEL sebagai sinyal kondisi bermasalah Bank Perkreditan Rakyat di wilayah DIY, diperoleh kesimpulan sebagai berikut:

Capital Adecuacy Ratio (CAR) berpengaruh terhadap kondisi bermasalah untuk tiga bulan kedepan, atau dengan kata lain CAR berpotensi sebagai indikator sinyal kondisi bermasalah Bank Perkreditan Rakyat di wilayah DIY.

Non Performance Loan (NPL) berpengaruh terhadap kondisi bermasalah untuk tiga bulan kedepan, atau dengan kata lain NPL berpotensi sebagai indikator sinyal kondisi bermasalah Bank Perkreditan Rakyat di wilayah DIY untuk tiga bulan kedepan.

Penyisihan Penghapusan Aktiva produktif (PPAP) berpengaruh terhadap kondisi bermasalah untuk tiga bulan kedepan, atau dengan kata lain PPAP berpotensi sebagai indikator sinyal kondisi bermasalah Bank Perkreditan Rakyat di wilayah DIY untuk tiga bulan kedepan.

Profit Margin (PM) tidak berpengaruh terhadap kondisi bermasalah untuk tiga bulan kedepan, atau dengan kata lain PM berpotensi sebagai indikator sinyal kondisi bermasalah Bank Perkreditan Rakyat di wilayah DIY untuk tiga bulan kedepan.

Return On Assets (ROA) tidak berpengaruh terhadap kondisi bermasalah untuk tiga bulan kedepan, atau dengan kata lain ROA berpotensi sebagai indikator sinyal kondisi bermasalah Bank Perkreditan Rakyat di wilayah DIY untuk tiga bulan kedepan.

Loan to Deposit Ratio (LDR) berpengaruh terhadap yal kondisi bermasalah untuk tiga 
bulan kedepan, atau dengan kata lain LDR berpotensi sebagai indikator sinyal kondisi bermasalah Bank Perkreditan Rakyat di wilayah DIY untuk tiga bulan kedepan.

\section{Implikasi Hasil Penelitian}

\section{a. Implikasi Teoritis}

Pengaruh CAR sebagai indikator sinyal kondisi bermasalah dari penelitian ini terbukti, sehingga secara teoritis mendukung teori. Semakin rendah rasio CAR maka akan menjadi sinyal semakin besar kemungkinan suatu bank akan menghadapai kondisi bermasalah. Namun berbeda dengan penelitian sebelumnya yang dilakukan oleh Widiharto terhadap BPR di wilayah JABODETABEK, dimana hasilnya tidak terbukti.

Pengaruh NPL dan PPAP sebagai indikator sinyal kondisi bermasalah dari penelitian ini terbukti, sehingga secara teoritis mendukung teori. Rasio NPL dan PPAP yang merupakan proksi dari assets quality berpengaruh positip signifikan terhadap sinyal kondisi bermasalah BPR di DIY untuk 3 bulan kedepan. Semakin tinggi rasio aktiva produktif bermasalah maka akan menjadi sinyal semakin besar kemungkinan suatu bank akan menghadapai kondisi bermasalah. Hasil ini mendukung teori. Hal ini merupakan dampak pemberian kredit yang tingkat kolektibiltasnya rendah, sehingga dana yang dikelola tidak produktif dalam menghasilkan laba sebagaimana diharapkan. Penelitian sebelumnya yang dilakukan Widiharto pengaruh NPL terbukti, sedangkan pengaruh PPAP tidak terbukti sebagai indikator kondisi bermasalah pada BPR di JABODETABEK. Pengaruh PM sebagai indikator sinyal kondisi bermasalah dari penelitian ini tidak terbukti, sehingga secara teoritis tidak mendukung teori. Hasil penelitian Widiharto terhadap BPR di wilayah JABODETABEK hasilnya juga tidak terbukti. Pengaruh ROA sebagai indikator sinyal kondisi bermasalah dari penelitian ini tidak terbukti, sehingga secara teoritis tidak mendukung teori. Secara teoritis tidak mendukung. Hasil penelitian ini berbeda dengan hasil penelitian Widiharto di wilayah JABODETABEK, dimana hasilnya terbukti. Pengaruh LDR sebagai indikator sinyal kondisi bermasalah dari penelitian ini terbukti, sehingga secara teoritis mendukung teori.

\section{b. Implikasi Manajerial}

Hasil penelitian ini memberikan bukti empiris manfaat rasio keuangan CAMEL sebagai sinyal kondisi bermasalah. Rasio CAR sebagai proksi faktor likuiditas adalah rasio keuangan yang dapat digunakan untuk mengetahui adanya sinyal kondisi bermasalah dalam waktu pendek yaitu 3 bulan. BPR perlu memberikan perhatian khusus terhadap rasio CAR dalam menghindari kondisi bermasalah. Hal ini konsisten dengan Surat Edaran Bank Indonesia No. 30/3/UPPB tanggal 30 April 1997 tentang Tata Cara Penilaian Tingkat Kesehatan Bank Perkreditan Rakyat, dimana bobot faktor permodalan porsinya tinggi yaitu 30\%. Rasio NPL dan PPAP sebagai proksi faktor Assets Quality adalah rasio keuangan yang dapat digunakan untuk mengetahui adanya sinyal kondisi bermasalah dalam waktu pendek yaitu 3 bulan. BPR perlu memberikan perhatian khusus terhadap rasio NPL dan PPAP ini dalam menghindari kondisi bermasalah. Penurunan rasio NPL dan PPAP dengan cara menghindari pemberian kredit yang berpotensi macet merupakan langkah antisipatif untuk menghindari kondisi bermasalah. Hal seperti ini dampaknya dapat dikurangi atau dicegah dengan cara: (1). Pengawas memiliki kewenangan untuk melakukan konsolidasi; (2). Kebijakan kredit harus jelas dan rinci; (3). Informasi kepemilikan, kredit dan investasi mudah diketahui oleh public; (4). Dilaksanakannya good corporate governance terutama keterlibatan pemegang saham dan pengurus bank agar ikut bertanggung jawab pebuh apabila bank mengalami kesulitan. Hal ini konsisten dengan Surat Edaran Bank Indonesia No. 30/3/UPPB tanggal 30 April 1997 tentang Tata Cara Penilaian Tingkat Kesehatan Bank Perkreditan Rakyat, dimana bobot faktor kualitas aktiva produktif 
porsinya tinggi yaitu 30\%. Rasio LDR sebagai proksi faktor likuiditas adalah rasio keuangan yang juga dapat digunakan untuk mengetahui adanya sinyal kondisi bermasalah dalam waktu pendek yaitu 3 bulan kedepan. LDR adalah rasio yang menunjukkan seberapa jauh kemampuan bank dalam membayar kembali penarikan dana yang dilakukan deposan dengan mengandalkan kredit yang diberikan sebagai sumber likuiditasnya. Oleh sebab itu, LDR harus dikendalikan sehingga tidak menimbulkan masalah, dengan cara antara lain: (1). Menjaga porsi besarnya penyaluran kredit; (2). Menjaga image bank agar tidak terjadi rush.; (3). Memberikan service exelent agar loyalitas nasabah terjaga.

\section{DAFTAR PUSTAKA}

Algifari. 2000. Analisis Regresi, Teori, Kasus dan Solusi. Edisi 2. Yogyakarta: BPFE-UGM

Astuti Yuli Setyani. 2002. Analisis Kinerja Perusahaan Perbankan Sebelum dan Sesudah Menjadi Perusahaan Publik Di Bursa Efek Jakarta (BEJ). Tesis Program Pasca Sarjana Magister Akuntansi Universitas Diponegoro (tidak dipublikasikan).

Bahtiar Usman.2003. Analisis Rasio Keuangan Dalam Memprediksi Perubahan Laba Pada Bank-Bank di Indonesia: Media Riset Bisnis dan Manajemen. Vol.3. No.1. April 2003. pp. 59-74.

Desfian.Basran 2005. Analisis Faktor-faktor Yang Berpengaruh Terhadap Kinerja Bank Umum di Indonesia Tahun 2001-2008. Tesis Program Pasca Sarjana Magister Manajemen Universitas Diponegoro (tidak dipublikasikan).
Etty
M. Na s s e r. 2003 . Perbandingan Kinerja Bank Pemerintah dan Bank Swasta Dengan Rasio CAMEL Serta Pengaruhnya

Terhadap Harga Saham. Media Riset Akuntansi, Auditing dan Informasi. Vol.3. No.3. Desember 2003: 217-236.

Gitman, Lawrence J. (2000), Principles of Managerial Finance, International edition, Ninth Edition, San Diego State University, Canada.

Gujarati, Damodar, (1997), Ekonometrika Dasar, Erlangga, Jakarta.

Hair, Jr., Joseph F, Rolph E. Anderson, Ronald L.Tatman, and William C. Black, (1995), Multivariate Data Analysis With Reading, Fifth Edition, New York : Mac Millan Publishing Company

Harahap, Sofyan Syafri, (1999), Analisis Kritis atas Laporan Keuangan, Raja Grafindo Persada, Jakarta.

Helfert, E. A., 1991, Analisis Laporan Keuangan (terj. Herman Wibowo), Edisi Ketujuh, Penerbit Erlangga, Jakarta

Hunger, J. David \& Thomas. L. Wheelen. 2002. Manajemen Strategis, Edisi 2. Andi. Yogyakarta.

Imam Ghozali (2002), Analisis Multivariate Lanjutan Dengan Program SPSS, Badan Penerbit Universitas Diponegoro, Semarang.

Imam Ghozali. 2005. Aplikasi Analisis Multivariate Dengan Program SPSS. Edisi 3. Badan Penerbit Universitas Diponegoro. Semarang.

Indira Januarti (2002), Variabel Proksi CAMEL dan Karakteristik Bank Lainnya untuk Memprediksi Kondisi bermasalah Bank di Indonesia, Jurnal Bisnis Strategi Vol. 10/ Desember/ Th. VII/ 2002. 
Indira Januarti. 2002 . Variabel Proksi CAMEL dan Karakteristik Bank Lainnya Untuk Memprediksi Kebangkrutan Bank di Indonesia. Jurnal Bisnis Strategi. Vol.10. Desember. Hal 1-26.

Institut Bankir Indonesia (1999), Kamus Perbankan Indonesia, Institut Bankir Indonesia, Jakarta.

Lembaran Negara RI (1998), Undangundang No. 10 Tahun 1998 Tentang Perbankan, Jakarta.

Luciana Spica Almilia dan Winny Herdiningtyas (2005), Analisis Rasio CAMEL terhadap Prediksi Kondisi Bermasalah pada Lembaga Perbankan Perioda 2000-2002, Jurnal Akuntansi dan Keuangan, Vol. 7 No. 2, Nopember 2005.

Mas'ud Machfoedz (1994), Financial Ratio Analysis and The Predictions of Earnings Changes in Indonesia, Kelola, No. 7/III/, Universitas Gajah Mada : 114-137.

Mawardi, Wisnu. 2005. Analisis Faktor-faktor Yang Mempengaruhi Kinerja Keuangan Bank Umum di Indonesia. Jurnal Bisnis Dan Strategi. Vol.14. No.1. Juli 2005.
Mucharor Djalil. 2006. Ra t i ng 131 B a n $\mathrm{k}$. Info Bank. No.327. Edisi Juni 2006.

Mulyo Budi Setiawan. 2004. Arsitektur Perbankan Indonesia Sebagai Upaya Memperkokoh Fundamental Perbankan Nasional. FOKUS Ekonomi. Vol.3. No.1. April 2004. Hal 38-51.

Nasser, Etty M dan Titik Aryati. 2000. "Model Analisis CAMEL Untuk Memprediksi Financial Distress Pada Sektor Perbankan Yang Go Publik. ".JAAI. Vol.4. No.2.

Evaluasi Kinerja Perusahaan Perbankan Sebelum dan Sesudah Menjadi Perusahaan Publik di Bursa Effek Jakarta, Kelola, No. 20/VIII/1999, Universitas Gajah Mada : 54-69.

Peraturan Bank Indonesia Nomor: 13/26/PBI/2011 Tanggal 28

Desember 2011 Tentang Perubahan Atas Peraturan Bank Indonesia Nomor 8/19/PBI/2006 Tentang Kualitas Aktiva produktif Dan Pembentukan Penyisihan Penghapusan Aktiva produktif Bank Perkreditan Rakyat. 


\section{LAMPIRAN}

\section{DATA PENAIIIAY}

\begin{tabular}{|c|c|c|c|c|c|c|c|c|c|c|c|c|c|c|}
\hline No & & BPR & CAR & Gmoup & NPL & GROUP & PPAP & GROUP & $\mathbf{P M}$ & GROUP & ROA & GROUP & LDR & GROUP \\
\hline 2 & BANIUL-2 & BPR Swailharma Artha Nus & 28.38 & $\mathbf{1}$ & 10.01 & 1 & 169 & $\mathbf{0}$ & 14.34 & $\mathbf{1}$ & 2.36 & 1 & 78.00 & $\mathbf{0}$ \\
\hline 4 & BANIUL-4 & PT_BPR Arga Tath & 18.42 & 1 & 18.66 & 1 & 3.24 & 1 & 8.91 & $\mathbf{0}$ & -0.66 & $\mathbf{0}$ & 77.70 & $\mathbf{0}$ \\
\hline 5 & BANIUL-5 & PT_BPR Artha Parama & 11.18 & $\mathbf{0}$ & 5.42 & $\mathbf{0}$ & 0.71 & $\mathbf{0}$ & 6.53 & 0 & 0.69 & $\mathbf{0}$ & 70.07 & $\mathbf{0}$ \\
\hline 6 & BANIUL-6 & PT.BPR ArumManifri Kemanga & 1187 & $\mathbf{0}$ & 9.12 & $\mathbf{1}$ & 0.90 & $\mathbf{0}$ & 13.00 & 1 & 3.14 & $\mathbf{1}$ & 74.90 & $\mathbf{0}$ \\
\hline $\mathbf{9}$ & BANIUL-9 & PT BPR Kartikartha Kencanajuya & 38.41 & 1 & 3.60 & $\mathbf{0}$ & 3.13 & 1 & 20.75 & 1 & 3.15 & 1 & 66.02 & $\mathbf{0}$ \\
\hline 10 & BANTUL-10 & PT. BPR Knmia Sewm & 13.45 & $\mathbf{0}$ & 5.10 & 0 & 0.86 & 0 & 14.37 & $\mathbf{1}$ & 3.15 & $\mathbf{1}$ & 80.93 & $\mathbf{1}$ \\
\hline 11 & BANTUL-11 & PT_BPR Nusamba B angyntzpan & 12.37 & $\mathbf{0}$ & 2.52 & $\mathbf{0}$ & 2.27 & 1 & 277 & $\mathbf{0}$ & 0.49 & $\mathbf{0}$ & 80.89 & $\mathbf{1}$ \\
\hline 12 & BANIUL 12 & PT.DPR Pofidhm Pacanitra & 12.10 & $\mathbf{0}$ & G.59 & $\mathbf{0}$ & 1.34 & $\mathbf{0}$ & G.n. & $\mathbf{0}$ & 175 & $\mathbf{0}$ & 66.87 & $\mathbf{0}$ \\
\hline 13 & BANIUL-13 & PT_BPR Swatharma Bangun Artha & 17.82 & 1 & 15.17 & 1 & 3.20 & 1 & 1284 & 1 & 205 & 1 & 87.51 & 1 \\
\hline 14 & BANIUL-14 & PT_BPR Tanin Artha & 17.18 & 1 & 13.95 & $\mathbf{1}$ & 221 & $\mathbf{0}$ & -43.81 & $\mathbf{0}$ & -8.88 & 0 & 78.14 & $\mathbf{0}$ \\
\hline 19 & SIEMAN5 & PT_BPR Arta Y gyylanta & 11.98 & $\mathbf{0}$ & 9.85 & 1 & 293 & 1 & 274 & $\mathbf{0}$ & 0.66 & $\mathbf{0}$ & 88.04 & 1 \\
\hline 20 & SIFMAN 6 & PT_BPR Artzajya Bhaktimulya & 28.27 & 1 & 16.47 & 1 & 3.07 & 1 & 3.92 & o & 0.90 & 0 & 70.84 & $\mathbf{0}$ \\
\hline 21 & SIFMAN-7 & PT_BPR ArthaMlatinith & 40.02 & 1 & $12 n$ & $\mathbf{0}$ & 0.86 & $\mathbf{0}$ & 30.91 & 1 & 8.09 & 1 & 59.97 & 0 \\
\hline $\mathbf{2 2}$ & SIFMAN8 8 & PT_BPR Artha Sumber Alam & 1178 & $\mathbf{0}$ & 4.46 & 0 & 139 & $\mathbf{0}$ & 13.42 & 1 & 276 & $\mathbf{1}$ & 87.27 & $\mathbf{1}$ \\
\hline $\mathbf{2 3}$ & SIEMUN-9 & PT_BPR Betlian Bumi Arta & 13.72 & $\mathbf{0}$ & 2.93 & 0 & 4.23 & 1 & 5.65 & $\mathbf{0}$ & 1.30 & $\mathbf{0}$ & 63.98 & $\mathbf{0}$ \\
\hline 24 & SLFMAN-10 & PT_BPR Bhaldi Daya Flanomi & 12.52 & $\mathbf{0}$ & 284 & $\mathbf{0}$ & 1.10 & $\mathbf{0}$ & 12.99 & 1 & 281 & 1 & 79.55 & 1 \\
\hline 25 & SIFMAN-11 & PT_BPR Bhmilarya Pah & 14.98 & $\mathbf{0}$ & 6.59 & 0 & 242 & 1 & 244 & $\mathbf{0}$ & 265 & 1 & 106.33 & 1 \\
\hline 26 & SIEMAN-12 & PT_BPR Danagung Alad & 11.57 & $\mathbf{0}$ & 4.46 & 0 & 205 & 0 & 8.62 & 1 & 26 & $\mathbf{1}$ & 72.55 & $\mathbf{0}$ \\
\hline 27 & SLEMAN-13 & PT BPR Danagung Eladti & 13.37 & $\mathbf{0}$ & 4.86 & $\mathbf{0}$ & 201 & 0 & 14.92 & 1 & 3.88 & 1 & 77.79 & $\mathbf{0}$ \\
\hline 28 & SIEMNH-14 & PT_ BPR Danagung Ramulti & 14.78 & $\mathbf{0}$ & 4.94 & $\mathbf{0}$ & $2 \pi$ & 1 & 12.51 & 1 & 3.24 & 1 & 74.56 & $\overline{\mathbf{0}}$ \\
\hline $\mathbf{2 9}$ & SIFMAN-15 & PT. BPR Danamas Prima & 17.92 & 1 & 6.91 & 0 & 1.66 & $\mathbf{0}$ & $13 . n$ & 1 & 294 & 1 & 79.87 & $\mathbf{1}$ \\
\hline 38 & SIFMAN-24 & PT_BPR Shinh Daya & 10.77 & $\mathbf{0}$ & 240 & $\mathbf{0}$ & 292 & 1 & 12.53 & 1 & 3.02 & 1 & 89.55 & 1 \\
\hline 39 & SIEMAN-25 & PT_BPR Siniln Adi & 17.51 & 1 & 7.70 & $\mathbf{0}$ & 3.45 & 1 & 7.81 & 1 & 1.92 & $\mathbf{0}$ & 85.26 & 1 \\
\hline 40 & SLEMWN-26 & PT_BPR Universitas Gajah Math & 1182 & $\mathbf{0}$ & 4.06 & $\mathbf{0}$ & 5.50 & $\mathbf{1}$ & 18.28 & 1 & 3.31 & 1 & 84.99 & 1 \\
\hline 41 & SIEMAN-27 & PT_BPR Wigyamulya Santms & 16.78 & $\mathbf{0}$ & 6.50 & $\mathbf{0}$ & 0.90 & $\mathbf{0}$ & 13.12 & 1 & 279 & 1 & 66.92 & $\mathbf{0}$ \\
\hline 42 & KOTA-1 & PT_BPR Artha Bertah Cemeriang & 2147 & 1 & 10.75 & $\mathbf{1}$ & 2.44 & $\mathbf{1}$ & -18.72 & o & -2.37 & $\mathbf{0}$ & 79.79 & $\mathbf{1}$ \\
\hline 43 & KOTA-2 & PT_BPR Lestani Damo Mulyo & 15.82 & $\mathbf{0}$ & 5.11 & 0 & 172 & $\mathbf{0}$ & 15.74 & 1 & 3.93 & $\mathbf{1}$ & 89.11 & 1 \\
\hline 44 & KOTA-3 & PT_BPR Matani Segihtera Abail & 17.16 & 1 & 6.97 & 0 & 224 & $\mathbf{1}$ & 1294 & 1 & 3.15 & 1 & 86.27 & $\mathbf{1}$ \\
\hline 45 & KOTA-4 & PT. BPR Matarem Mitra Manneggal & 7.01 & $\mathbf{0}$ & 14.55 & $\mathbf{1}$ & 138 & 0 & -31.95 & 0 & -6.03 & $\mathbf{0}$ & 68.58 & $\mathbf{0}$ \\
\hline 46 & KOTA-5 & PT_BPR Walet Kyya Abadi & 21.92 & $\mathbf{1}$ & 7.14 & $\mathbf{0}$ & 0.78 & $\mathbf{0}$ & 13.43 & 1 & 3.43 & 1 & 65.57 & $\mathbf{0}$ \\
\hline 47 & KOTA-6 & PT BPR Bant JogyaKon Yogyalarta & 20.02 & 1 & 4.52 & $\mathbf{0}$ & 0.96 & $\mathbf{0}$ & 14.32 & 1 & 2.51 & 1 & 81.16 & 1 \\
\hline 48 & GnKidnt-1 & PT_BPR Agra Arthla Mulya & 1143 & $\mathbf{0}$ & 6.33 & 0 & $\mathbf{1 8 6}$ & $\mathbf{0}$ & 3.61 & $\mathbf{0}$ & 278 & $\mathbf{1}$ & 80.81 & 1 \\
\hline 49 & Gn-Kidnl-2 & PT_BPR Arum Manfini Metati & 1287 & $\mathbf{0}$ & 8.80 & $\mathbf{1}$ & 1.16 & 0 & 16.66 & $\mathbf{1}$ & 4.30 & $\mathbf{1}$ & 82.02 & $\mathbf{1}$ \\
\hline 50 & GnKidn13 & PT_BPR Bank Daenh Guningtidul & 20.26 & 1 & 4.01 & 0 & $\mathbf{1 0 1}$ & o & 14.14 & 1 & 276 & $\mathbf{1}$ & 87.87 & 1 \\
\hline 51 & GnKidn14 & PT_BPR Urabima Nintya Rahaig & 15.46 & $\mathbf{0}$ & 6.37 & 0 & $\mathbf{1 8 7}$ & $\mathbf{0}$ & 10.03 & $\mathbf{1}$ & 215 & $\mathbf{1}$ & 84.69 & 1 \\
\hline 52 & Kln-Progo-1 & PT. BPR BP Kulm Prugo & 27.44 & 1 & 4.25 & 0 & 179 & $\mathbf{0}$ & 15.82 & 1 & 262 & $\mathbf{1}$ & 84.34 & 1 \\
\hline 53 & Kln-Froge-2 & PT_ BPR Nusamba Temon & 17.24 & 1 & 3.06 & 0 & 1.18 & 0 & 2.19 & o & 0.58 & 0 & 84.58 & $\mathbf{1}$ \\
\hline 54 & Kln-Frogo-3 & PT_BPR Shint Puta Pangash & 8.34 & $\mathbf{0}$ & 9.87 & 1 & 5.99 & 1 & 4.56 & o & 0.26 & 0 & 99.53 & $\mathbf{1}$ \\
\hline \multirow{2}{*}{\multicolumn{15}{|c|}{$\begin{array}{c}\mid 7.71 \\
\text { JUIAH BPR }\end{array}$}} \\
\hline & & & & & & & & & & & & & & \\
\hline \multirow{2}{*}{\multicolumn{4}{|c|}{$\begin{array}{l}\text { DUATAS RATARATA (1) } \\
\text { DEFAWHARATA RATA (0) } \\
\end{array}$}} & 21 & & 17 & & $\mathbf{n}$ & & 34 & & 36 & & 32 \\
\hline & & & & 33 & & 37 & & 32 & & 20 & & 18 & & $\boldsymbol{n}$ \\
\hline \multicolumn{4}{|c|}{ NMTNHEPR } & 54 & & 54 & & 54 & & 54 & & 54 & & 54 \\
\hline \multicolumn{15}{|c|}{ PERAENTANE (\%) } \\
\hline
\end{tabular}


JURNAL AKUNTANSI. VOL.1 NO.1 JUNI 2013

\section{UJI NORMALITAS}

\begin{tabular}{|c|c|c|c|c|c|c|}
\hline \multirow{2}{*}{$\begin{array}{l}\text { Date: 01/20/13 } \\
\text { Sample: } 1270\end{array}$} & \multicolumn{6}{|l|}{ Time: 08:36 } \\
\hline & CAR & NPL & PPAP & PM & ROA & LDR \\
\hline Mean & 5.528431 & 3.494448 & 1.302788 & 4.579743 & 1.482845 & 3.540617 \\
\hline Median & 5.401379 & 3.649099 & 1.181671 & 5.080369 & 1.982793 & 3.633821 \\
\hline Maximum & 7.774231 & 7.376258 & 5.355282 & 10.81900 & 9.038135 & 6.050212 \\
\hline Minimum & 0.570358 & -3.121295 & -0.976267 & -4.391819 & -9.210340 & 0.030973 \\
\hline Std. Dev. & 0.860407 & 1.796952 & 1.333015 & 1.886323 & 2.028308 & 1.000000 \\
\hline Skewness & -0.020493 & -0.925861 & 0.440187 & -1.141399 & -1.159397 & $\begin{array}{r}-0.312826 \\
\end{array}$ \\
\hline Kurtusis & 0.051503 & 4.092207 & 2.027127 & 0.301997 & 7.519722 & 3.503220 \\
\hline Jarque-Bera & 150.0205 & 78.85743 & 10.28352 & 181.2864 & 290.3029 & 7.972482 \\
\hline Probability & 0.000000 & 0.000000 & 0.005847 & 0.000000 & 0.000000 & 0.018569 \\
\hline Sum & 1492.676 & 943.5009 & 351.7527 & 1236.531 & 400.3681 & 955.9666 \\
\hline Sum Sq. Dev. & 199.1406 & 868.6107 & 477.9939 & 957.1592 & 1106.675 & 269.0000 \\
\hline Observations & 270 & 270 & 270 & 270 & 270 & 270 \\
\hline
\end{tabular}

\section{UJI MULTIKOLINEARITAS}

\begin{tabular}{|c|c|c|c|c|c|c|}
\hline & CAR & NPL & PPAP & PM & ROA & LDR \\
\hline CAR & 1.000000 & -0.132647 & -0.028924 & 0.108745 & 0.077850 & -0.246175 \\
\hline NPL & -0.132647 & 1.000000 & 0.330270 & -0.154411 & -0.141016 & -0.064187 \\
\hline PPAP & -0.028924 & 0.330270 & 1.000000 & -0.146546 & -0.147188 & 0.149120 \\
\hline PM & 0.108745 & -0.154411 & -0.146546 & 1.000000 & 0.636407 & 0.017471 \\
\hline ROA & 0.077850 & -0.141016 & -0.147188 & 0.636407 & 1.000000 & -0.178238 \\
\hline LDR & -0.246175 & -0.064187 & 0.149120 & 0.017471 & -0.178238 & 1.000000 \\
\hline
\end{tabular}

\section{UJI HETEROKEDASTISITAS}

Dependent Variable: RESIDU

Method: Least Squares

Date: 01/27/13 Time: 00:12

Sample: 1270

Included observations: 270

White Heteroskedasticity-Consistent Standard Errors \& Covariance

\begin{tabular}{crlcr}
\hline \hline Variable & Coefficient & Std. Error & t-Statistic & Prob. \\
\hline \hline CAR & 0.298318 & 0.226118 & 1.319303 & 0.1882 \\
NPL & -0.337112 & 0.241358 & -1.396730 & 0.1637 \\
PPAP & 0.113752 & 0.096788 & 1.175268 & 0.2409 \\
PM & 0.006710 & 0.072531 & 0.092508 & 0.9264 \\
ROA & 0.034007 & 0.037781 & 0.900093 & 0.3689 \\
LDR & -0.024595 & 0.059367 & -0.414283 & 0.6790 \\
\hline \hline R-squared & -0.112575 & Mean dependent var & 0.292593 \\
Adjusted R-squared & -0.133647 & S.D. dependent var & 0.455798 \\
S.E. of regression & 0.485301 & Akaike info criterion & 1.413876 \\
Sum squared resid & 62.17647 & Schwarz criterion & 1.493841 \\
Log likelihood & -184.8733 & Hannan-Quinn criter. & 1.445987 \\
Durbin-Watson stat & 0.743152 & & & \\
\hline \hline
\end{tabular}

UJI

\begin{tabular}{|c|c|c|c|c|}
\hline \multicolumn{5}{|c|}{$\begin{array}{l}\text { Dependent Variable: RESIDU } \\
\text { Method: Least Squares } \\
\text { Date: } 01 / 20 / 13 \text { Time: } 17: 38 \\
\text { Sample (adjusted): } 2270 \\
\text { Included observations: } 269 \text { after adjustments }\end{array}$} \\
\hline Variable & Coefficient & Std. Error & t-Statistic & Prob. \\
\hline CAR & 0.598485 & 0.075520 & 7.924811 & 0.0000 \\
\hline NPL & 0.009089 & 0.086903 & 0.104586 & 0.9168 \\
\hline PPAP & 0.824970 & 0.096610 & 8.539200 & 0.0000 \\
\hline PM & -0.020606 & 0.107275 & -0.192083 & 0.8478 \\
\hline ROA & 0.816761 & 0.061180 & 13.35014 & 0.0000 \\
\hline LDR & 1.155236 & 0.079992 & 14.44197 & 0.0000 \\
\hline R-squared & -0.689521 & \multirow{6}{*}{\multicolumn{2}{|c|}{$\begin{array}{l}\text { Mean dependent var } \\
\text { S.D. dependent var } \\
\text { Akaike info criterion } \\
\text { Schwarz criterion } \\
\text { Hannan-Quinn criter. }\end{array}$}} & 6.420134 \\
\hline Adjusted R-squared & -0.721641 & & & 0.998150 \\
\hline S.E. of regression & 1.309686 & & & 3.399504 \\
\hline Sum squared resid & 451.1181 & & & 3.479684 \\
\hline Log likelihood & -451.2334 & & & 3.431705 \\
\hline Durbin-Watson stat & 1.804870 & & & \\
\hline
\end{tabular}


Dependent Variable: MASALAH

Method: ML - Binary Logit (Quadratic hill climbing)

Date: 02/08/13 Time: 09:19

Sample: 1270

Included observations: 270

Convergence achieved after 6 iterations

Covariance matrix computed using second derivatives

\begin{tabular}{crrrr}
\hline \hline \multicolumn{1}{c}{ Variable } & Coefficient & Std. Error & z-Statistic & Prob. \\
\hline \hline CAR & -1.437321 & 0.263837 & -5.447773 & 0.0000 \\
NPL & 5.728545 & 0.901489 & 6.354537 & 0.0000 \\
PPAP & 1.191378 & 0.322282 & 3.696696 & 0.0002 \\
PM & -0.501289 & 0.380233 & -1.318371 & 0.1874 \\
ROA & 0.057734 & 0.411552 & 0.140282 & 0.8884 \\
LDR & -1.524385 & 0.348822 & -4.370093 & 0.0000 \\
\hline \hline Mean dependent var & 0.292593 & S.D. dependent var & 0.455798 \\
S.E. of regression & 0.236698 & Akaike info criterion & 0.427101 \\
Sum squared resid & 14.79083 & Schwarz criterion & 0.507066 \\
Log likelihood & -51.65858 & Hannan-Quinn criter. & 0.459211 \\
Avg. log likelihood & -0.191328 & & & \\
\hline \hline Obs with Dep=0 & \multicolumn{5}{|c}{ Total obs } & \\
Obs with Dep=1 & 79 & & \\
\hline \hline
\end{tabular}

